Boston University School of Law

Scholarly Commons at Boston University School of Law

Faculty Scholarship

1997

Tobacco Litigation as Cancer Prevention: Dealing with the Devil

George J. Annas

Follow this and additional works at: https://scholarship.law.bu.edu/faculty_scholarship

Part of the Health Law and Policy Commons 
Legal Issues in Medicine

\section{Tobacco Litigation as Cancer Prevention: Dealing with the Devil}

\author{
George J. AnNAS, J.D., M.P.H.
}

$\mathrm{T}$ OBACCO companies have come to personify the devil, and strategies to exorcise tobacco smoking from the United States proliferate. Tobacco's demonic status is even reflected in popular fiction. John Grisham's latest bestseller, The Runaway Jury, for example, is a broadside attack on tobacco companies. He opens the book by noting that tobacco companies "had been thoroughly isolated and vilified by consumer groups, doctors, even politicians." "This was bad, but it was getting even worse: "Now the lawyers were after them."

Physicians often see trial lawyers as predators, but choosing sides between lawyers and big tobacco has, at least recently, seemed easy. The American Medical Association (AMA), for example, now endorses "all avenues" of litigation against the tobacco companies as a public health strategy. ${ }^{2}$ As New York Times reporter Philip J. Hilts puts it in a recently published book, "The natural end for a tangle like the tobacco wars is in court." 3

Lawsuits against tobacco companies are not a new phenomenon, but until 1996 they seemed singularly impotent. Chroniclers of tobacco litigation identify three waves of litigation. ${ }^{3,4}$ The first dates from the time medical research first demonstrated the risks of cancer from smoking and continued until the early 1970s (1954 to 1973 ). The second wave (1983 to 1992 ) began in the early 1980s and ended with the dropping of the Cipollone case (the subject of a previous column ${ }^{5}$ ). Tobacco companies paid nothing to claimants in any of these lawsuits, ultimately winning them all by relying on three arguments: smoking is the result of a free choice, there is no conclusive proof that tobacco causes disease, and the industry supports research on the effects of smoking on health. ${ }^{3,6}$ The third wave, which dates from 1994, is seen as much more likely to succeed, because of the discovery of a vast array of previously secret documents that undercut the industry's own arguments, including documents indicating that the industry knew nicotine was addictive and used this knowledge to hook users. ${ }^{7,8}$ A new study that shows how a tar ingredient, benzo(a)pyrene, causes cancer by affecting the P53 gene is prompting tobacco companies to rethink their position on causation. ${ }^{9,10}$ Moreover, while plaintiff lawyers had previously been totally outgunned financially by tobacco companies willing to pay virtually any price not to lose a case, third-wave cases have been brought by teams of law firms and by state attorneys general with the help of private lawyers. ${ }^{7}$ The playing field has been leveled to such an extent that discussions have begun on how Congress might act to settle all tobacco lawsuits in a fair manner.

\section{THIRD-WAVE CLASS-ACTION SUITS}

The class action that can be said to have marked the beginning of the third wave is Castano v. American Tobacco Co., filed on March 29, 1994, in federal district court in Louisiana. ${ }^{11}$ Represented by more than 60 law firms, the class seeks damages from the tobacco companies only for the somewhat ambiguous "injury of nicotine addiction." The trial court defined the class broadly to include

(a) All nicotine-dependent persons in the United States . . . who have purchased and smoked cigarettes manufactured by the tobacco companies;

(b) the estates, representatives, and administrators of these nicotine-dependent cigarette smokers; and

(c) the spouses, children, relatives, and "significant others" of those nicotine-dependent cigarette smokers and their heirs or survivors. ${ }^{11}$

A "nicotine-dependent" person was defined as any smoker "who has been diagnosed by a medical practitioner as nicotine-dependent" or as any "regular cigarette smoker" who has been "advised by a medical practitioner that smoking has had or will have adverse health consequences" and who thereafter did not quit smoking. ${ }^{11}$ This is, of course, a potentially giant class, comprising millions of people. For any group to be certified as a class under the Federal Rules of Civil Procedure, the court must find, among other things, that "the questions of law or fact common to the members of the class predominate over any questions affecting only individual members, and that a class action is superior to other available methods for the fair and efficient adjudication of the controversy." 12 The trial court so found, but the case was reversed on appeal and the class decertified. $^{12}$

As described by the appeals court, the key to the plaintiffs' complaint was the "wholly untested theory" that the tobacco companies "fraudulently failed to inform consumers that nicotine is addictive and manipulated the level of nicotine in cigarettes to sustain their addictive nature." 12 Specific allegations included fraud and deceit, the intentional infliction of emotional distress, violation of state consumer-protection statutes, breach of warranty, and strict product liability. ${ }^{12}$ The remedy sought was compensatory and punitive damages, attorneys' fees, an admission of wrongdoing, and the use of profits for restitution and to establish a fund for medical monitoring. The appeals court refused to certify this as a class action, 
primarily because it believed that the trial court had considered neither how variations in the state laws would affect the outcome of individual cases nor how a trial on the merits of the cases would actually be conducted. ${ }^{12}$

Concerning the issues of state law, the appeals court noted that "in a multi-state class action, variations in state law may swamp any common issues" because states have different legal rules, "including matters of causation, comparative fault, and the types of damages available. . . ."12 Specifically, the court noted that the members of the class had used "different tobacco products for different amounts of time and over different periods." 12 Knowledge of the dangers of smoking differed from person to person, as did the reason for the use of the product in the first place. The appeals court found the idea of millions of individual cases formidable but concluded, "Absent considered judgment on the manageability of the class, a comparison to millions of individual trials is meaningless." 12 The court stated, "The collective wisdom of individual juries is necessary before this court commits the fate of an entire industry or indeed, the fate of a class of millions, to a single jury." 12 This May 1996 decision was a serious blow to all tobacco-related class-action lawsuits. Nonetheless, the plaintiffs almost immediately set about filing separate state class actions regarding addiction, and have already done so in about a dozen states. $^{13}$

\section{STATE REIMBURSEMENT SUITS}

Potentially more important than class-action suits are suits to reimburse states for medical costs; 19 states and more than a dozen cities, including New York City, have sued the tobacco companies on behalf of taxpayers to recover the share of Medicaid costs and payments for the uninsured that are attributable to tobacco-induced disease. The states are being aided by outside private counsel working on the basis of contingency fees. All of the state lawsuits include allegations of fraud and causing addiction, but the claims themselves vary. ${ }^{14}$ The first case, for example, was filed in May 1994 by the attorney general of Mississippi, Mike Moore. The Mississippi lawsuit, which is set for trial in March 1997, rests on theories of unjust enrichment and restitution that are based on the claim that the state's taxpayers have been injured directly by the tobacco industry by having to pay the medical costs of the illnesses induced by tobacco products. ${ }^{7}$

The second suit, filed by Attorney General Hubert $\mathrm{H}$. Humphrey III, of Minnesota, alleges that tobacco companies committed both antitrust conspiracy and consumer fraud in engaging in a "unified campaign of deceit and misrepresentation" to conceal information about addictiveness from the public. $^{7}$ In early October 1996, Humphrey filed a newly discovered 1980 internal memorandum from the British-American Tobacco Company, which he characterized as "an astounding disclosure" of the time when the tobacco companies decided to continue their "deadly cover-up" instead of admitting the truth for the sake of their "integrity." 15 The memo argued that acknowledging that cigarettes cause cancer would put the tobacco companies in a more credible position, positioning them "alongside the liquor industry as being socially responsible, in that we acknowledge our products can be harmful in excess." 15 The memo also contained a warning, "If the predictions of the U.S. lawyers are correct, we could lose a cancer suit, and this could lead to a new 'industry' in America and elsewhere, that of suing tobacco companies, costing a lot of money." 15 Such evidence also strengthens racketeering allegations under the Racketeer Influence and Corrupt Organizations Act (RICO), recently permitted to proceed in Florida, which could result in triple damages against the tobacco companies. ${ }^{13}$

These cases mark the first time states have sued anyone for having injured people for whom the state was in turn obligated to pay medical bills. ${ }^{14}$ Robert I. Rabin of Stanford Law School has said that given the novelty of the cases, it is impossible to predict how they will fare, noting, "It is possible that with all the revelations [of company wrongdoing] there will be a much greater likelihood of overcoming the freedom of choice argument." 14 Assuming that one or more of these state-sponsored reimbursement lawsuits is successful, the question of measuring damages may be difficult. Of the smokers who die of smoking-related illnesses, most do not die until after they become eligible for Medicare. Thus, the cost of their final illness (other than long-term care expenses) is likely to be borne not by the city or the state, but by the federal government. Moreover, to the extent that the individual smoker dies earlier than he or she would otherwise have died, the federal government may even get a net savings from Social Security and Medicare - and also from Medicaid, which pays for nursing home care for nonsmokers who live longer than smokers. The extent to which federal financial burdens and benefits should be factored into state-level judgments, or whether the federal government should itself be a party to these cases, remains to be determined.

\section{INDIVIDUAL-SMOKER LAWSUITS}

Although class actions and state-sponsored lawsuits are the main characteristics of the third wave of tobacco litigation, individual lawsuits have been given new life by the discovery of industry documents - such as that uncovered by Humphrey - concerning addiction, the concealment of research, and obfuscation. ${ }^{3,8}$ For the first time, a jury awarded 
damages $(\$ 750,000)$ to a smoker, Grady Carter, of Jacksonville, Florida, in August 1996 (in Cipollone, the damages were awarded to the smoker's spouse). ${ }^{16}$ Lung cancer developed in the 65-year-old Mr. Carter after he had been smoking for 43 years. The jury found that Brown and Williamson, the makers of Lucky Strike cigarettes, had failed to properly warn Carter of the risks of smoking before the time that warning labels were required by federal law. The case was the first in which internal Brown and Williamson documents were admitted into evidence, and the jury seems to have been convinced that the company should have informed the public about the addictiveness of nicotine. Interviews with three of the six jurors revealed that two of them were angry at what they saw as the company's hypocritical defense: the company had accumulated "reams of evidence" that smoking was harmful but continued to tell the public that the hazards of smoking were not proved. ${ }^{16}$ The jury also seems to have been impressed that Mr. Carter admitted some responsibility for continuing to smoke (he picked a physician who smoked so he would not be pressured by his doctor to quit), sought a relatively small amount of money (\$1.5 million), and did not ask for punitive damages. ${ }^{16}$

In reaction to the Carter case, the stock prices of Philip Morris and RJR Nabisco dropped 14 percent and 13 percent, respectively, in one day, even though these tobacco companies were not directly involved in the litigation. ${ }^{16}$ Their stock prices later recovered, however, and the entire industry breathed a bit easier (and its stock prices rose) when a jury returned a verdict for the defense in a later case, in Indiana, in which the company's internal documents were not admitted into evidence. ${ }^{17}$ The Florida verdict has rekindled interest in pursuing individual lawsuits, and a string of even relatively small victories could go a long way toward putting the tobacco companies out of business, as their shareholders seem to realize. Carter's attorney, Norwood Wilner, has another 200 cases filed and plans to bring 1 case a month to trial. ${ }^{16}$

\section{POSSIBLE GLOBAL SETTLEMENTS}

In March 1996 the Liggett Group, the smallest of the major U.S. tobacco companies, offered to settle four of the five state suits then pending and the Castano class action. Liggett offered to pay each state (Florida, Massachusetts, Mississippi, and West Virginia) $\$ 4$ million over a period of 10 years and between 2 and 7 percent of its pretax income over 24 years and to settle Castano by paying another 5 percent of pretax income for 25 years for programs to help people stop smoking. ${ }^{18}$ The company also agreed not to give out free samples or use cartoon characters in its ads. ${ }^{18}$ The deal was originally proposed by Liggett's majority shareholder, Bennett
S. LeBow, and included the right of any company Liggett merged with to make the same deal. LeBow's goal was to influence RJR Nabisco's shareholders to vote for a merger with his company. Liggett retained the right to withdraw from the agreement if the other tobacco companies won their suits on the merits, and the company could terminate the Castano portion if the class certification was reversed on appeal (as it was). The deal would have cost Liggett approximately $\$ 31$ million over 25 years, far less than it would be likely to spend on legal fees. ${ }^{18}$

Liggett did settle with five states, has agreed to pay each $\$ 1$ million, and intends to pursue settlement with the other states. But the merger did not succeed, no other company joined Liggett, and the proposal may still unravel. ${ }^{19}$ LeBow had indicated that his company "just can't afford a scorched-earth litigation policy. . . . One major judgment against Liggett would put us out of business." $19 \mathrm{He}$ continues to encourage the larger tobacco companies to pursue a global settlement. ${ }^{19}$

One such global-settlement proposal was floated in August 1996 by attorney Richard Scruggs, who is working with Mississippi's attorney general and apparently has the backing of Scruggs's brother-in-law, Senate Majority Leader Trent Lott. Under the proposal, the tobacco companies would pay about $\$ 6$ billion in the form of grants to the $\mathbf{5 0}$ states in 1997, with the cost for each company based on the number of cigarettes it sells in the United States. ${ }^{20,21}$ Thereafter, the manufacturers would contribute about $\$ 100$ billion over a period of 15 years - or between 30 and 40 cents for every pack sold. ${ }^{20}$ In addition to dismissing all the state suits, Congress would take jurisdiction over tobacco and adopt the regulations of the Food and Drug Administration (FDA) on advertising directed at young people as law. ${ }^{20,22}$ Jurisdiction would, however, return to the FDA if smoking rates among young people failed to decline within a specific period (the industry was said to see this as a "deal breaker"). ${ }^{21}$ Lawsuits would be drastically curtailed for the next 15 years, although specific details were not made public. Damages for pending lawsuits would be capped. ${ }^{23}$ The mere fact that this proposal was seriously discussed for a couple of weeks is noteworthy; it may be the basis of further discussions in the next Congress, which is the body that would have to enact any such global arrangement for it to be effective. ${ }^{23}$

Richard Kluger, the author of Ashes to Ashes, had earlier suggested an alternative global settlement:

1. Congress would [grant blanket] . . . immunity to the tobacco companies against all pending and future product liability claims. . . .

2. The FDA would be given regulatory oversight of the manufacture and packaging of cigarettes, including the power to set maximum levels for their hazardous ingredients. 
3. Health warning labels would be enlarged to occupy the entire back of all cigarette packs and would carry far more informative language.

4. . . . OSHA [Occupational Safety and Health Administration] regulations restricting smoking at most work places . . . and FDA [regulations regarding advertising would be promptly implemented]. . . .

5. The federal cigarette tax would be doubled to 48 cents to pay for enforcing these new regulations. An additional 2 -cents-a-pack levy would pay for an anti-smoking advertising campaign. . . . ${ }^{24}$

It is hard to imagine that more specific or larger warning labels would have much of an effect on smokers, and although raising the tax on cigarettes may discourage young smokers, it strikes hardest at addicted low-income smokers. ${ }^{25}$ Moreover, there seems to be no rationale for granting the tobacco companies blanket immunity for past wrongdoings - at least for lawsuits in which fraud can be proved. On the other hand, limited immunity may be a price worth paying for FDA regulatory authority over tobacco that would have a real chance to lead to cigarettes that are safer and contain progressively lower levels of nicotine. Both of these settlement proposals have serious shortcomings, but their existence is itself novel, and the search for some global settlement is gaining ground as litigation intensifies and the public's disgust with the tobacco industry grows.

The AMA recently indicated its distaste for the tobacco industry's projected (and probably protracted) litigation against the FDA's proposed regulations governing the access of children to tobacco products and advertising aimed at children. ${ }^{22}$ The organization has advised physicians to focus their antitobacco efforts on persuading their patients not to smoke (and helping them quit) and on working at the state and local level for antismoking legislation. ${ }^{26}$ This is reasonable advice. The new chief executive officer of RJR Nabisco, attorney Steven F. Goldstone, gave up cigarette smoking at his physician's insistence 17 years ago. ${ }^{27}$ Goldstone is happy, however, to have his customers risk their health with his tobacco products. In his words, "Not to be too red-white-andblue about it, but taking risks is what this country is about." ${ }^{27}$ And preventing unnecessary illness and injury is what public health is all about.

One risk Goldstone does not seem willing to take, however, is that society's increasing disgust with the tobacco companies will hold down the price of his company's stock. Thus, in an October 21, 1996, interview concerning third-quarter earnings, he said he was looking for a negotiated settlement to the legal war on tobacco, declaring: "I have to believe that both the industry and Congress - no matter who's in Congress - will be willing to talk about it. I'm confident President Clinton will as well." 28

The acceptability of any global settlement will, of course, depend on one's goals in the tobacco wars. Protecting individual choice while minimizing health hazards seems reasonable, as does putting tobacco under the jurisdiction of the Consumer Protection Agency. The 1980 internal tobacco-company memorandums had it right: cigarettes are a hazardous product that, like alcohol, should be recognized and regulated as such. Prohibition has not worked and will not work, and to the extent that the proposed OSHA workplace rules would amount to a total prohibition on smoking in all workplaces, they would not work either. The twin goals of reducing smoking and making smoking itself less addictive and safer are laudable. The percentage of adult tobacco smokers in the United States seems unlikely to grow larger than its current 25 percent and will most likely continue to decrease as the habit becomes even more socially unacceptable. It is also perfectly reasonable to restrict the access of children to cigarettes and ban advertising aimed at them something the tobacco companies can (and should) do voluntarily. Increasing taxes on cigarettes to fund antismoking advertising and smoking-cessation programs also seems reasonable, although using this regressive tax for other social programs (such as Medicaid) is unfair to addicted smokers.

The key to public health action on the tobacco front seems to lie in combining strategies to discourage children from smoking and in producing a safer and less addictive cigarette for those who cannot, or will not, resist the temptation to smoke. A truly global settlement must transcend U.S. boundaries, and a U.S. settlement should help set worldwide standards for tar and nicotine. ${ }^{29}$ Litigation has many problems, but to the extent that litigation has made a global settlement at least possible, it is time to work out reasonable terms.

\section{REFERENCES}

1. Grisham J. The runaway jury. New York: Doubleday, 1996.

2. Todd JS, Rennie D, McAfee RE, et al. The Brown and Williamson doc uments: where do we go from here? JAMA 1995;274:256-8.

3. Hilts PJ. Smoke screen: the truth behind the tobacco industry cover-up. Reading, Mass.: Addison-Wesley, 1996:195.

4. Daynard RA, Kelder GE. Waiting to exhale. Boston Globe. February 11, 1996:81.

5. Annas GJ. Health warnings, smoking, and cancer - the Cipollone case. N Engl J Med 1992;327:1604-7.

6. Kluger R. Ashes to ashes: America's hundred-year cigarette war, the public health, and the unabashed triumph of Philip Morris. New York: Knopf, 1996.

7. Kelder GE, Daynard RA. Tobacco litigation as a public health and cancer control strategy. JAMWA 1996;51:57-62

8. Glantz SA, Slade J, Bero LA, Hanaher P, Barnes DE. The cigarette papers. Berkeley: University of California Press, 1996.

9. Hwang SL. Tobacco firms may shift tack on cancer link. Wall Street Journal. October 21, 1996:B1.

10. Denissenko MF, Pao A, Tang M-s, Pfeifer GP. Preferential formation of benzo[a]pyrene adducts at lung cancer mutational hotspots in P53. Science 1996;274:430-2.

11. Castano v. American Tobacco Co., 160 F.R.D. 544 (1995)

12. Castano v. American Tobacco Co., 84 F.3d 734 (1996).

13. MacLachlan C. More RICO counts for tobacco. National Law Journal. January 6, 1997:A7. 
14. Idem. Now spotlight is on states in tobacco war. National Law Journal. June 3, 1996:Al

15. AG: tobacco papers are 'astounding.' National Law Journal. October 21, 1996:A5.

16. Hwang SL, Geyelin M, Freedman AM. Jury's tobacco verdict suggests tough times ahead for the industry. Wall Street Journal. August 12, 1996:Al. 17. Gevelin M. Is tobacco trial a 'must win' for industry? Wall Street Journal. August 21, 1996:B1.

18. Freeman AM, Hwang SL, Lipin S, Geyelin M. Breaking away: Liggett group offers first-ever settlement of cigarette lawsuits. Wall Street Journal, March 13, 1996:Al.

19. Feder BJ. Liggett's tobacco settlement in danger of coming undone. New York Times. September 7, 1996:38.

20. Gevelin M. States greet plan to settle tobacco suits with skepticism, but leave door open. Wall Street Journal. August 29, 1996:B14.

21. Idem. Plan to settle tobacco cases draws fire. Wall Street Journal. August 27, 1996:A3.
22. Annas GI Cowboys, camels, and the first amendment - the FDA's restrictions on tobacco advertising. N Engl J Med 1996;335:1779-83. 23. Weiser B. SmokeEnders. Washington Post Magazine. December 8 , 1996:15-9, 28-35.

24. Kluger R. A peace plan for the cigarette wars: dance with the devil New York Times Magazine. April 7, 1996:28-54.

25. Sugarman SD. Smoking guns. Science 1996;273:744-5.

26. The smoke hasn't cleared. American Medical News. October 14 1996:17.

27. Feder BJ. Keeping cool in a roomful of smoke at RJR Nabisco. New York Times. July 28, 1996:F1.

28. Hwang SL. RJR's profit rose $4 \%$ in third period; stock price frustrates chief executive. Wall Street Journal. October 22, 1996:B12.

29. Gray N. The global cigarette. BMJ 1996;313:1348.

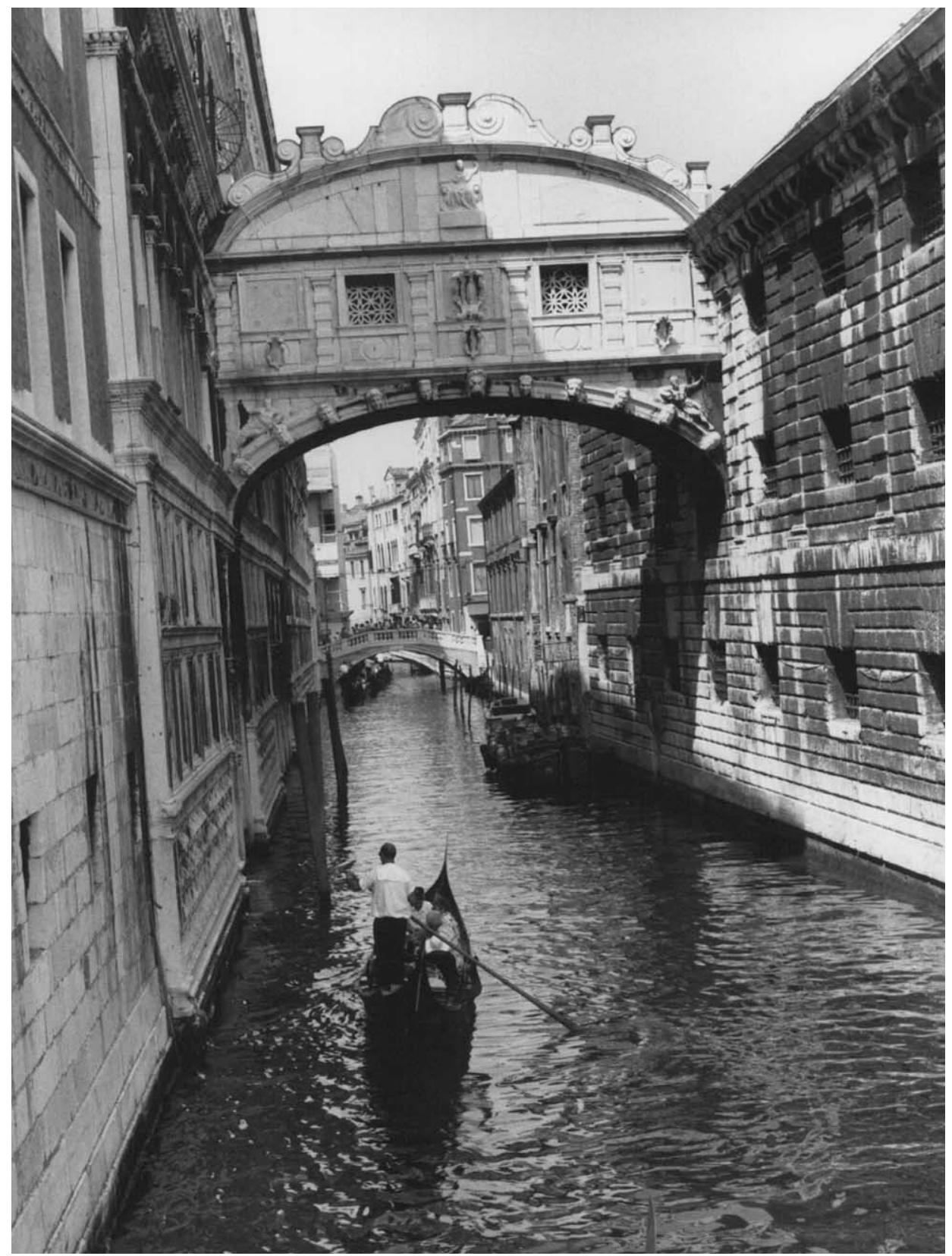

Venice 